\title{
Effects of triclabendazole and nitroxynil on EPG, hematological parameters and body weight against fascioliasis in goats at government goat development farm, Sylhet, Bangladesh
}

\author{
Khanam $\mathrm{S}^{1}$, Islam $\mathrm{MS}^{1}$, Aktaruzzaman $\mathrm{M}^{1 *}$, Hossain $\mathrm{MA}^{1}$, Hossain $\mathrm{MM}^{3}$, Hossain $\mathrm{MK}^{4}$, \\ Mamun $\mathrm{MA}^{5}$, Noor $\mathrm{M}^{5}$ and Howlader $\mathrm{MMR}^{2}$ \\ ${ }^{1}$ Department of Pharmacology and Toxicology, ${ }^{2}$ Department of Physiology, ${ }^{3}$ Department of Medicine, \\ ${ }^{4}$ Department of Surgery and Theriogenology, ${ }^{5}$ Department of Pathology, Faculty of Veterinary and Animal \\ Science, Sylhet Agricultural University, Sylhet-3100, Bangladesh
}

[Received: August 24, 2015; Accepted: November 12, 2015]

\begin{abstract}
The study was conducted to evaluate the effects of triclabendazole and nitroxynil against fascioliasis in goat for a period of 28 days on 20 black bengal goats. Among hundred goats, twenty were selected for this study which was suffering from liver fluke (Fasciola gigantica) infection and were marked by tagging. Twenty goats were randomly divided into four groups (A, B, C and D) where each group comprising of five goats. Group A were treated with tablet fasinex (triclabendazole, Novartis Ltd, Bangladesh) orally at the dose rate of $12 \mathrm{mgkg}^{-1}$ body weight, group B were treated with acinex (triclabendazole, ACI Ltd, Bangladesh) orally at the dose rate of 12 $\mathrm{mgkg}^{-1}$ body weight and group C were treated with nitronex injection (nitroxynil, Renata Ltd, Bangladesh) subcutaneously at the dose rate of $10 \mathrm{mgkg}^{-1}$ body weight. Goats of group D was kept as infected control group without giving any treatment. A significant $(\mathrm{P}<0.01)$ reduction of egg per gram $(\mathrm{EPG})$ count was found on $7^{\text {th }}$, $14^{\text {th }}, 21^{\text {st }}$ and $28^{\text {th }}$ days of treated goats of group A, B and C, respectively. The EPG count of control group were significantly $(\mathrm{P}<0.01)$ increased 7 day onwards up to experimental period. Reduction of mean EPG on $7^{\text {th }}, 14^{\text {th }}$, $21^{\text {st }}$ and $28^{\text {th }}$ day after treatment in group A, B and C were $81.48 \%, 81.25 \%$ and $83.04 \%$, respectively, whereas in control group the mean EPG were $22.43 \%$. Of the hematological parameters, TEC, Hb and PCV values were lower on day 0 but turned to increase $(\mathrm{p}<0.01)$ on day 28 of the study. On the other hand, ESR and TLC were higher before treatment (day 0$)$ but decreased significantly $(\mathrm{p}<0.01)$ on day 28.The body weight increased significantly $(\mathrm{P}<0.01)$ after treatments in group A, B and C respectively except untreated control. This result may indicate that three commercial anthelmintics contain triclabendazole and nitroxynil against fascioliasis in goat and nitroxynil have higher efficacies on egg per gram (EPG), hematological parameters and body weight against fascioliasis in goat. Additional detailed studies are required to prevent and control of fascioliasis in goats by using a routine prophylactic anthelmintics measurement.
\end{abstract}

Key words: Anthelmintics, triclabendazole, nitroxynil, eggs per gram (EPG), hematology, body weight, fascioliasis, goats

\section{INTRODUCTION}

Bangladesh is an agro-economy based developing countries of the world. The livestock is an important sub-sector which is considered to be the backbone of agriculture in Bangladesh ${ }^{[1]}$ and approximately $80 \%$ people depend on it directly or indirectly for their subsistence. The livestock population in Bangladesh is currently estimated to comprise 26.828 million cattle, 0.544 million buffalo, 16.242 million goat and 1.221 million sheep ${ }^{[2]}$ which plays an important role in the rural economy [3]. Fascioliasis, caused by Fasciola hepatica and $F$. gigantica, is one of the most prevalent helminthes infections of ruminants in different parts of the world inducing significant morbidity and mortality ${ }^{[21]}$ as well as lower production of ruminants ${ }^{[20] .}$ This group of liver fluke (Fasciola sp.) is also associated with anaemia ${ }^{[28]}$ resulting loss of body weight, stunted growth, diarrhea etc. that greatly hamper the normal growth and production of goat. The mortality rates are $5 \%$ due to fascioliasis infestation in goat in Bangladesh [5]. The agro-ecological and geo-climatic condition of Bangladesh is highly favorable for the growth and multiplication of parasites. The heavy rainfall in the summer and autumn, deep fog in the winter and also low lying region might be the causes of higher prevalence of the disease in Bangladesh [18]. Prevalence of fascioliasis is higher during the rainy season in slaughtered goats [11]. The reason for the more prevalence of Fasciola sp. after summer season may be due to conductive factors like presence of marshy places with grass at the canal banks and presence of snails in the area reported by [31]. Outbreaks of fascioliasis occurred after flooding reported by ${ }^{[35] .}$ Especially rainfall climate conditions 
were often associated with prevalence of the fasciola infection because this was suitable for intermediate host like snails to reproduce and to survive longer under humid conditions ${ }^{[4]}$. The use of sustainable, integrated parasite control systems, using scientifically proven non-chemical methods and limited use of drugs is being considered to ensure animal health and food safety [34]. The present investigation was aimed to evaluate the effects of three commercial anthelmintics against fascioliasis in goats and their effects on the basis of EPG count, body weight of goats and hematological parameters like total erythrocyte count (TEC), hemoglobin \% $(\mathrm{Hb} \%)$, packed cell volume (PCV), erythrocyte sedimentation rate (ESR) and total leukocyte count (TLC) were also included in this investigation.

\section{MATERIALS AND METHODS}

\section{Experimental period and location}

This study was conducted for a period of 28 days at government goat development farm, Sylhet $\left(24.909221^{\circ} \mathrm{N} 91.901986^{\circ} \mathrm{E}\right)$ under the supervision of the Department of Physiology and Pharmacology, Faculty of Veterinary and Animal Science, Sylhet Agricultural University $\left(24.909221^{\circ} \mathrm{N} 91.901986^{\circ} \mathrm{E}\right)$, Sylhet, Bangladesh to evaluate the effects of triclabendazole and nitroxynil against fascioliasis on EPG, hematological parameters and body weight in goats. The study protocol was approved by the ethical committee of the government goat development farm, Sylhet, Bangladesh.

\section{Experimental goats and their management}

Twenty goats of 1.5-2 years old are weighing between 16 to $17 \mathrm{~kg}$ were selected randomly which were severely infected with fascioliasis. All the goats were reared under standard farm managemental procedure.

\section{Experimental design}

Twenty goats were randomly divided into four groups each comprising of five goat and marked as A, B, C and D. Goats of group A were treated with tablet fasinex (Triclabendazole, Novartis Ltd, Bangladesh) orally at the dose rate of $12 \mathrm{mgkg}^{-1}$ body weight, group $\mathrm{B}$ were treated with acinex (triclabendazole, ACI Ltd, Bangladesh) orally at the dose rate of $12 \mathrm{mgkg}^{-1}$ body weight and group $\mathrm{C}$ were treated with nitronex injection (nitroxynil, Renata Ltd, Bangladesh) subcutaneously at the dose rate of $10 \mathrm{mgkg}^{-1}$ body weight and goats of group D served as untreated control.

\section{Measurement of EPG and live weight of goat}

Weekly EPG count was done on day $7^{\text {th }}, 14^{\text {th }}, 21^{\text {st }}$, $28^{\text {th }}$ post treatment by McMaster egg counting technique. McMaster fecal egg count method described by ${ }^{[8]}$ was used. The percentage of reduction of EPG (eggs per gram) was calculated as $\mathrm{N} 1-\mathrm{N} 2 / \mathrm{N} 1 \times 100 ; \mathrm{N} 1=$ Number at day " 0 "; N2 = Number on next counting day. The body weight of all goats was taken as described by ${ }^{[29]}$. Body weight $=$ Length $\times(\text { Girth })^{2} / 300 \times 2.2 \mathrm{~kg}$. Here Length $=$ Length from the point of shoulder to the buttock in inches. Girth was also measured in inches at the point of xyphoid cartilage.

\section{Collection of blood sample}

With sterile syringe and needle maintaining aseptic condition, $5 \mathrm{ml}$ of blood sample was collected from jugular vein of each goat and kept in vials containing anticoagulant (sodium- EDTA) and this was done on day of $0,7^{\text {th }}, 14^{\text {th }}, 21^{\text {st }}$ and $28^{\text {th }}$ during experimental period. All the goat of treated and control groups were closely observed for 28 days after treatment.

\section{Fecal and hematological examination}

The fecal samples were collected from the treated and control groups of goat on $7^{\text {th }}, 14^{\text {th }}, 21^{\text {st }}$ and $28^{\text {th }}$ day of treatment to investigate the fecal egg count and were immediately brought to the Physiology and Pharmacology Laboratory, Sylhet, Bangladesh for fecal examination. The blood samples were collected from the treated and untreated control groups on the day ' 28 ' of treatment and hematological parameters TEC, Hb, PCV, ESR and TLC were determined as per method by ${ }^{[6,15] \text {. }}$

\section{Statistical analysis}

All the data were statistically analyzed by the statistical package programmed MSTAT-C developed by ${ }^{[24]}$ and following the standard methods by ${ }^{[27]}$ to find out the level of significance at 1 and $5 \%$ level. The mean difference among the treatments was determined as per Dancan's Multiple Range Test [10]. The eggs of parasites were identified on the basis of morphological characteristics as described by ${ }^{[28]}$ and then counted. 


\section{RESULTS AND DISCUSSION}

\section{Effects of triclabendazole and nitroxynil on egg count EPG (eggs per gram) in goats}

The result of the effects of three commercial anthelmintics against fascioliasis in goats is presented in (Table 1). In the treatment group A, mean EPG count before treatment $216.00 \pm 10.77$ and after treatment mean EPG on $7^{\text {th }}, 14^{\text {th }}, 21^{\text {st }}$ and $28^{\text {th }}$ day were $68.00 \pm 5.26,60.00 \pm 5.24,52.00 \pm 5.83$ and $40.00 \pm 1.52$, respectively. The rates of reduction of mean EPG on 28th day after treatment were $81.48 \%$, respectively.

In treatment group B, the pre-treatment mean EPG count was $208.00 \pm 0.63$ and the post-treatment mean EPG count values at $7^{\text {th }}, 14^{\text {th }}, 21^{\text {st }}$ and $28^{\text {th }}$ day were $66.00 \pm 4.00,58.00 \pm 1.89,50.00 \pm 2.74$ and $39.00 \pm 2.15$, respectively. The rates of reductions were significantly increased to the extent of mean EPG on $28^{\text {th }}$ day after treatments were $81.25 \%$, respectively.

In treatment group $\mathrm{C}$, the pre-treatment mean EPG feces. A significant $(\mathrm{P}<0.01)$ reduction of EPG count was found on $7^{\text {th }}, 14^{\text {th }}, 21^{\text {st }}$ and $28^{\text {th }}$ day of treated goat of group A, B and C, respectively. This findings support the earlier works of $[30,26,33,7,22,17]$ in goat, sheep and cattle. On the other hand, the EPG count of control group were significantly $(\mathrm{P}<0.01)$ increased 7 day onwards up to study period. This study supports the previous findings recorded by ${ }^{[13]}$. More than $98 \%$ efficacy in hill sheep flocks in the west of Ireland reported by ${ }^{[19]}$. However it could be concluded that, nitroxynil is a potent anthelmintic from the family of substituted phenols that is utilized in ruminants for the control of trematodes, particularly for Fasciola hepatica ${ }^{\text {[23]. }}$

\section{Effects of triclabendazole and nitroxynil on hematological parameters in goats}

The effects of triclabendazole and nitroxynil on hematological parameters against fascioliasis in goats were shown in (Table 2).

Total Erythrocyte Count (TEC): The pre-treatment values of TEC (million/cu. $\mathrm{mm}$ of blood) were

Table 1. Effects of triclabendazole and nitroxynil on egg count EPG (eggs per gram) against fascioliasis in goats

\begin{tabular}{|c|c|c|c|c|c|c|c|}
\hline \multirow[t]{2}{*}{ Groups } & \multirow{2}{*}{ Treatment } & \multirow{2}{*}{$\begin{array}{l}\text { Pre-treatment } \\
\text { Day } 0\end{array}$} & \multicolumn{5}{|c|}{ Post-treatment } \\
\hline & & & Day 7 & Day 14 & Day 21 & Day 28 & $\begin{array}{l}\% \text { Reduction } \\
\text { at day " } 28 \text { " }\end{array}$ \\
\hline & & 216.00 & 68.00 & 60.00 & 52.00 & 40.00 & \\
\hline $\mathrm{G}_{\mathrm{A}}$ & Fasinex ${ }^{\circledR}$ & $\begin{array}{c} \pm \\
10.77\end{array}$ & $\stackrel{ \pm}{ \pm .26 * *}$ & $\stackrel{ \pm}{ \pm .24 * *}$ & $\stackrel{ \pm}{ \pm .83} * *$ & $\stackrel{ \pm}{ \pm}$ & 81.48 \\
\hline $\mathrm{G}_{\mathrm{B}}$ & Acine $x \circledR$ & $\begin{array}{c}208.00 \\
\pm \\
6.63\end{array}$ & $\begin{array}{c}66.00 \\
\pm \\
4.00^{* *}\end{array}$ & $\begin{array}{c}58.00 \\
\pm \\
1.89^{* *}\end{array}$ & $\begin{array}{c}50.00 \\
\pm \\
2.74 * *\end{array}$ & $\begin{array}{c}39.00 \\
\pm \\
2.15^{* *}\end{array}$ & 81.25 \\
\hline $\mathrm{G}_{\mathrm{C}}$ & Inj. Nitronex ® & $\begin{array}{c}224.00 \\
\pm \\
10.29\end{array}$ & $\begin{array}{c}76.00 \\
\pm \\
2.09 * *\end{array}$ & $\begin{array}{c}50.00 \\
\pm \\
5.68 * *\end{array}$ & $\begin{array}{c}76.00 \\
\pm \\
2.55^{* *}\end{array}$ & $\begin{array}{c}38.00 \\
\pm \\
0.89^{* *}\end{array}$ & 83.04 \\
\hline $\mathrm{G}_{\mathrm{D}}$ & Control group & $\begin{array}{c}214.00 \\
\pm \\
17.21\end{array}$ & $\begin{array}{c}230.00 \\
\pm \\
4.47 * *\end{array}$ & $\begin{array}{c}252.00 \\
\pm \\
7.35^{* *}\end{array}$ & $\begin{array}{c}255.00 \\
\pm \\
7.24 * *\end{array}$ & $\begin{array}{c}262.00 \\
\pm \\
6.52 * *\end{array}$ & 22.43 \\
\hline
\end{tabular}

$* *=$ Significant at 1 percent level $(\mathrm{p}<0.01$ and $\mathrm{p}>0.05)$

count was $224.00 \pm 10.29$ and the post-treatment mean EPG count values at $7^{\text {th }}, 14^{\text {th }}, 21^{\text {st }}$ and $28^{\text {th }}$ day were $76.00 \pm 2.09,50.00 \pm 5.68,76.00 \pm 2.55$ and $38.00 \pm 0.89$, respectively. The rates of reductions were significantly increased to the extent of mean EPG on $28^{\text {th }}$ day after treatments were $83.04 \%$, respectively. Mean body weight of untreated control group D (day 0 ) EPG count was $214.00 \pm 17.21$ and on the EPG count values at $7^{\text {th }}, 14^{\text {th }}, 21^{\text {st }}$ and $28^{\text {th }}$ day were $230.00 \pm 4.47, \quad 252.00 \pm 7.35, \quad 255.00 \pm 7.24$ and $262.00 \pm 6.52$, respectively and the rate of EPG count was increased to the extent of mean EPG on $28^{\text {th }}$ day were $22.43 \%$, respectively.

The effects of anthelmintic were evaluated on the basis of the percentage of reduction in mean egg count compared to the mean egg count per gram of
$7.60 \pm 0.34,7.56 \pm 0.19$ and $7.78 \pm 0.26$ in the goat of group $\mathrm{A}, \mathrm{B}$ and $\mathrm{C}$, respectively. On the $28^{\text {th }}$ day of the post-treatment, the mean values of TEC were increased up to $8.38 \pm 0.25,8.36 \pm 0.21$ and $8.42 \pm 0.17$ in the goat of group $\mathrm{A}, \mathrm{B}$ and $\mathrm{C}$, respectively. The mean value of TEC in control group (group D) was $7.74 \pm 0.26$ but the mean values of TEC started to decrease on $28^{\text {th }}$ day and recorded as $6.70 \pm 0.24$. The mean value of TEC was significantly increased $(p<0.01)$ on $28^{\text {th }}$ day of the treatment of three anthelmintics. These results are more or less similar with the earlier researchers of ${ }^{[14,12,30,32]}$ in goat, sheep, calf and cattle. The improved level of TEC content of blood in treated goat might be due to elimination of parasites. 
Hemoglobin $(\mathrm{Hb})$ concentration: The pre-treatment values of $\mathrm{Hb}(\mathrm{g} \%)$ were $8.44 \pm 0.25,8.40 \pm 0.40$ and $8.60 \pm 0.48$ in the goat of group A, B and C, respectively. On the $28^{\text {th }}$ day of the post-treatment, the mean values of $\mathrm{Hb}(\mathrm{g} \%)$ were increased up to of PCV in control group (group D) was 27.95 \pm 0.02 but the mean values of PCV started to decrease on $28^{\text {th }}$ day and recorded as $25.10 \pm 0.07$. The mean value of PCV was significantly increased $(\mathrm{p}<0.01)$ on $28^{\text {th }}$ day of three anthelmintics treatment. Similar results

Table 2. Effects of triclabendazole and nitroxynil on hematological parameters against fascioliasis in goats

\begin{tabular}{|c|c|c|c|c|c|c|c|c|c|c|c|}
\hline \multirow[t]{3}{*}{ Groups } & \multirow[t]{3}{*}{ Treatment } & \multicolumn{5}{|c|}{ Pre-treatment } & \multicolumn{5}{|c|}{ Post-treatment } \\
\hline & & \multicolumn{5}{|c|}{ Day 0} & \multicolumn{5}{|c|}{ Day 28} \\
\hline & & TEC & $\mathrm{Hb}$ & PCV & ESR & TLC & TEC & $\mathrm{Hb}$ & PCV & ESR & TLC \\
\hline $\mathrm{G}_{\mathrm{A}}$ & Fasinex $®$ & $\begin{array}{c}7.60 \\
\pm \\
0.34\end{array}$ & $\begin{array}{c}8.44 \\
\pm \\
0.25\end{array}$ & $\begin{array}{c}28.40 \\
\pm \\
0.07\end{array}$ & $\begin{array}{c}0.98 \\
\pm \\
0.004\end{array}$ & $\begin{array}{c}8.14 \\
\pm \\
0.037\end{array}$ & $\begin{array}{c}8.38 \\
\pm \\
0.25^{* *}\end{array}$ & $\begin{array}{c}9.72 \\
\pm \\
0.37 * *\end{array}$ & $\begin{array}{c}30.40 \\
\pm \\
0.04 * *\end{array}$ & $\begin{array}{c}0.68 \\
\pm \\
0.001 *\end{array}$ & $\begin{array}{c}7.60 \\
\pm \\
0.02 *\end{array}$ \\
\hline $\mathrm{G}_{\mathrm{B}}$ & Acine $x \circledR$ & $\begin{array}{c}7.56 \\
\pm \\
0.19\end{array}$ & $\begin{array}{c}8.40 \\
\pm \\
0.40\end{array}$ & $\begin{array}{c}28.34 \\
\pm \\
0.42\end{array}$ & $\begin{array}{c}0.97 \\
\pm \\
0.004\end{array}$ & $\begin{array}{c}8.08 \\
\pm \\
0.024\end{array}$ & $\begin{array}{c}8.36 \\
\pm \\
0.21^{* *}\end{array}$ & $\begin{array}{c}9.70 \\
\pm \\
0.23 * *\end{array}$ & $\begin{array}{c}29.98 \\
\pm \\
0.03 * *\end{array}$ & $\begin{array}{c}0.62 \\
\pm \\
0.007 *\end{array}$ & $\begin{array}{c}7.24 \\
\pm \\
0.02 *\end{array}$ \\
\hline $\mathrm{G}_{\mathrm{C}}$ & Inj. Nitronex ${ }^{\circledR}$ & $\begin{array}{c}7.78 \\
\pm \\
0.26\end{array}$ & $\begin{array}{c}8.60 \\
\pm \\
0.48\end{array}$ & $\begin{array}{c}28.98 \\
\pm \\
0.02\end{array}$ & $\begin{array}{c}1.02 \\
\pm \\
0.005\end{array}$ & $\begin{array}{c}8.34 \\
\pm \\
0.02\end{array}$ & $\begin{array}{c}8.42 \\
\pm \\
0.17 * *\end{array}$ & $\begin{array}{c}10.14 \\
\pm \\
0.16^{* *}\end{array}$ & $\begin{array}{c}30.82 \\
\pm \\
0.05^{* *}\end{array}$ & $\begin{array}{c}0.76 \\
\pm \\
0.008 *\end{array}$ & $\begin{array}{c}7.70 \\
\pm \\
0.019 *\end{array}$ \\
\hline $\mathrm{G}_{\mathrm{D}}$ & Control group & $\begin{array}{c}7.74 \\
\pm \\
0.26\end{array}$ & $\begin{array}{c}8.32 \\
\pm \\
0.31\end{array}$ & $\begin{array}{c}27.95 \\
\pm \\
0.02\end{array}$ & $\begin{array}{c}0.92 \\
\pm \\
0.008\end{array}$ & $\begin{array}{c}7.96 \\
\pm \\
0.013\end{array}$ & $\begin{array}{c}6.70 \\
\pm \\
0.24 * *\end{array}$ & $\begin{array}{c}7.40 \\
\pm \\
0.52 * *\end{array}$ & $\begin{array}{c}25.10 \\
\pm \\
0.07 * *\end{array}$ & $\begin{array}{c}1.20 \\
\pm \\
0.011 *\end{array}$ & $\begin{array}{c}8.58 \\
\pm \\
0.017 *\end{array}$ \\
\hline
\end{tabular}

TEC $=$ Total erythrocytes count $\mathrm{Hb}=$ Hemoglobin $; \mathrm{PCV}=$ Packed cell volume;

$\mathrm{ESR}=$ Erythrocyte Sedimentation Rate; TLC = Total leukocyte count; SE = Standard Error

$* *=$ Significant at 1 percent level $(\mathrm{p}<0.01) ; *=$ Significant at 5 percent level $(\mathrm{p}<0.05)$

$9.72 \pm 0.37,9.70 \pm 0.23$ and $10.14 \pm 0.16$ in the goat of group $\mathrm{A}, \mathrm{B}$ and $\mathrm{C}$, respectively. The mean value of $\mathrm{Hb}(\mathrm{g} \%)$ in control group (group D) was $8.32 \pm 0.31$ but the mean values of $\mathrm{Hb}(\mathrm{g} \%)$ started to decrease on $28^{\text {th }}$ day and recorded as $7.40 \pm 0.52$. The mean value of $\mathrm{Hb}(\mathrm{g} \%)$ was significantly increased $(\mathrm{p}<0.01)$ on $28^{\text {th }}$ day of three anthelmintics treatment. Similar results have also been stated with the earlier researchers of ${ }^{[9,25]}$ in goat, and camel. The increase in hemoglobin content of blood might be due to the increases of total erythrocytes in blood.

Packed Cell Volume (PCV): The pre-treatment have also been stated by the earlier workers of ${ }^{[9,25]}$ in goat and camel. The improved level of PCV content of blood in treated goat might be due to elimination of parasites.

Erythrocyte Sedimentation Rate (ESR): The initial control values of ESR $\left(\mathrm{mm} \mathrm{h}^{-1}\right)$ were $0.98 \pm 0.007$, $0.97 \pm 0.004$ and $1.02 \pm 0.005$ in the goatof group A, B and $\mathrm{C}$, respectively. On the $28^{\text {th }}$ day of the posttreatment, the mean values of $\operatorname{ESR}\left(\mathrm{mm} \mathrm{h}^{-1}\right)$ were decreased up to $0.68 \pm 0.01,0.62 \pm 0.007$ and $0.76 \pm 0.008$ in the goat of group A, B and C,

Table 3. Effects of triclabendazole and nitroxynil on bodyweight against fascioliasis in goats

\begin{tabular}{|c|c|c|c|c|c|c|}
\hline \multirow[t]{3}{*}{ Groups } & \multirow[t]{3}{*}{ Treatment } & \multirow{3}{*}{$\begin{array}{c}\text { Pretreatment } \\
\text { Day } 0 \\
\text { Body weight } \\
(\mathrm{kg})\end{array}$} & \multirow{2}{*}{\multicolumn{2}{|c|}{$\begin{array}{c}\text { Post-treatment } \\
\text { Day } 28\end{array}$}} & \multirow{3}{*}{$\begin{array}{l}\text { Live weight } \\
\text { gain/loss (kg) }\end{array}$} & \multirow{3}{*}{$\begin{array}{c}\text { Improvement } \\
(\%)\end{array}$} \\
\hline & & & & & & \\
\hline & & & Body weight (kg) & $\begin{array}{c}\% \\
\text { change }\end{array}$ & & \\
\hline $\mathrm{G}_{\mathrm{A}}$ & Fasinex ${ }^{\circledR}$ & $16.50 \pm 0.068$ & $17.50 \pm 0.068 * *$ & 1.02 & +1.02 & +2.12 \\
\hline $\mathrm{G}_{\mathrm{B}}$ & Acinex $®$ & $16.60 \pm 0.07$ & $17.00 \pm 0.065 * *$ & 0.40 & +0.40 & +2.42 \\
\hline $\mathrm{G}_{\mathrm{C}}$ & Inj. Nitronex ${ }^{\circledR}$ & $16.40 \pm 0.07$ & $17.60 \pm 0.07 * *$ & 1.20 & +1.20 & +2.95 \\
\hline $\mathrm{G}_{\mathrm{D}}$ & Control group & $16.30 \pm 0.13$ & $15.35 \pm 0.13 * *$ & -0.95 & -0.95 & -1.80 \\
\hline
\end{tabular}

values of PCV were $28.40 \pm 0.07,28.34 \pm 0.42$ and $28.98 \pm 0.02$ in the goat of group A, B and C, respectively. On the $28^{\text {th }}$ day of the post-treatment, the mean values of PCV were increased up to $30.40 \pm 0.04,29.98 \pm 0.03$ and $30.82 \pm 0.05$ in the goat of group A, B and C, respectively. The mean value respectively. The mean value of $\operatorname{ESR}\left(\mathrm{mm} \mathrm{h}^{-1}\right)$ in control group (group D) was $0.92 \pm 0.08$ but the mean values of ESR $\left(\mathrm{mm} \mathrm{h}^{-1}\right)$ started to increase on $28^{\text {th }}$ day and recorded as $1.20 \pm 0.011$. The mean value of ESR $\left(\mathrm{mm} \mathrm{h}^{-1}\right)$ was significantly decreased $(\mathrm{p}<0.05)$ 
on $28^{\text {th }}$ days of treatment. This result is similar to the reports of ${ }^{[14,30,9]}$ in calf, sheep and camel.

Total Leukocyte Count (TLC): The pre-treatment values of TLC were $8.14 \pm 0.037,8.08 \pm 0.024$ and $8.34 \pm 0.02$ in the goat of group A, B and C, respectively. On the $28^{\text {th }}$ day of the post-treatment, the mean values of TLC were decreased up to $7.60 \pm 0.02,7.24 \pm 0.02$ and $7.70 \pm 0.019$ in the goatof group $\mathrm{A}, \mathrm{B}$ and $\mathrm{C}$, respectively. The mean value of TLC in control group (group D) was $7.96 \pm 0.013$ but the mean values of TLC started to increase on $28^{\text {th }}$ day and recorded as $8.58 \pm 0.017$. The mean value of TLC was significantly decreased $(\mathrm{p}<0.05)$ on $28^{\text {th }}$ days of treatment. These present findings in agreement of the works with ${ }^{[32,25]}$ in goats. During the study of hematological parameters it was found that after treatment with fasinex, acinex and nitronex injection, TEC, $\mathrm{Hb}$ and $\mathrm{PCV}$ were significantly $(p<0.01)$ increased and on the other hand, ESR and TLC was significantly $(\mathrm{p}<0.05)$ decreased in treated groups. The mean value of $\mathrm{Hb}, \mathrm{PCV}$ and TEC were decreased and ESR, TLC values were increased in untreated control group.

\section{Effects of triclabendazole and nitroxynil on body weight}

The mean initial body weight on day ' 0 ' of goat in group $\mathrm{A}, \mathrm{B}$ and $\mathrm{C}$ were $16.50 \pm 0.068,16.60 \pm 0.07$ and $16.40 \pm 0.07 \mathrm{~kg}$ respectively was shown in (Table 3 ). On the $28^{\text {th }}$ day of the post-treatment, the mean values of body weight were increased up to $17.50 \pm 0.068,17.00 \pm 0.065$ and $17.60 \pm 0.07$ in the goat of group A, B and C, respectively. Mean body weight of untreated control group D (day 0) was $16.30 \pm 0.13$ and on the $28^{\text {th }}$ day were $15.35 \pm 0.13$. The body weight increased significantly $(\mathrm{P}<0.01)$ after treatments in group $\mathrm{A}, \mathrm{B}$ and $\mathrm{C}$. The body weight was increased and this may be due to removal of parasitic load might have facilitate the weight regain through proper absorption and metabolism of feed nutrient in the parasite free (Fasciola gigantica) goat reported by ${ }^{[16]}$ in dairy cow. On the other hand, the body weight significantly decreased in untreated control group (D) due to overload of parasites within the body of goat. The improvement percentage in goats of group $\mathrm{A}, \mathrm{B}$ and $\mathrm{C}$ after $28^{\text {th }}$ day was $2.12 \%$, $2.42 \%$ and $2.95 \%$, respectively. Some earlier workers found improvement in body weight after treatment ${ }^{[9,16]}$ in goat, sheep and cattle. In the control group (group D) body weight was reduces to the extent of $1.08 \%$ after $28^{\text {th }}$ day (Table 3 ).

\section{CONCLUSION}

The finding of the present study reveals that nitronex (nitroxynil) are highly effective on egg count (EPG), hematological parameters (TEC, Hb, PCV, ESR and TLC) and body weight in fascioliasis in goat than that of fasinex (triclabendazole) and acinex (triclabendazole) during the experiment. These three drugs having wide therapeutic index, cost effective and their market prices are within the reach of the farmers in our country. It was also observed that farms in these areas lack fences and cattle, sheep and goats use the same pasture for grazing. In this regard, it is suggested that practice of separate grazing of animals with low stocking rate may be adopted. It is therefore, suggested that anthelmentic treatment on quarterly basis may be implemented to reduce the risk of re-infection. Further study should be required to prevent the parasitic infection of the animals and maximizing the production.

\section{ACKNOWLEDGEMENT}

The authors are grateful to the livestock officer, all staffs at Government Goat Development Farm, Sylhet as well as Department of Physiology and Pharmacology for their financial assistance, kind help, scholastic guidance, constructive criticism, continuous inspiration and technical support in every step of this study.

\section{REFERENCES}

1. BBS, 1998. Agricultural Census 1983-84. Bangladesh Bureau of Statistics, Ministry of Planning, Dhaka, Bangladesh.

2. BBS, 2010. Report of the Household-based Livestock and Poultry Survey, 2009.

3. Kamaruddin KM, 2003. Goat farming as a means of poverty alleviation. In: Proceedings of BSVER symposium. Goats farming in Bangladesh; Problems and prospects. BAU. Bangladesh Society for Veterinary Education and Research. BSVER Publications. 25: 2634.

4. Ahmed EF, Markvichtr K, Tumwasorn S, Koonawootrittriron S, Choothesa A, Jittapalapong S, 2007. Prevalence of Fasciola spp. infections of sheep in the middle awash River Basin, Ethiopia. Southeast Asian J Trop Med Public Health, 38, 51-57.

5. BLRI, 2006. Bangladesh Livestock Research Institute, Funded by SICT program, Ministry of Planning, Government of the Peoples Republic of Bangladesh.

6. Coffin DL, 1995. Manual of Veterinary Clinical Pathology. Third ed. Coin stock Publishing Associates. Inc. Ithaca New York, 116-157.

7. Coles GC, Stafford KA, 2001. Activity of oxyclozanide, nitroxynil, clorsulon and albendazole against adult triclabendazoleresistant Fasciola hepatica. Vet Rec, 148, 723-724.

8. Gordon HMcL, Whitlock HV, 1939. A new technique for counting nematode eggs in sheep feces. JCSIR, Australia, 12:50-52.

9. Gillespie RAM, Williamson LH, Terrill TH, Kaplan RM, 2010. Efficacy of anthelmintic on South American camelid (llama and alpaca) 
farms in Georgia. Veterinary Parasitology, 172: 168-171.

10. Gomez KA, Gomez AA, 1984. Ducans multiple Ranges test. Statiscal procedures for agricultural Research. Second edition. John wiley and sons. pp: 207-215.

11. Hossain MM, Paul S, Rahman MM, Hossain FMA, Hossain MT, Islam MR, 2011. Prevalence and economic significance of caprine fascioliasis at Sylhet district of Bangladesh. Pak Vet J, 31, 113-116.

12. Islam SMN, Mostofa M, Rafiq K, Hoque MA, Islam MA, 1995. Comparative efficacy of Fasinex, Flukenil and Helmex against fascioliasis in dairy cattle. Bang. J. Anim. Sci, 27(12): 41-47.

13. Islam MA, Samad MA, 1989. Efficacy of commercial fasciolicides against mixed infection of fascioliasis and amphistomiasis in cattle. Bangladesh Vet, 6, 27-32.

14. Islam MA, Awal MA, Islam MR, Alam J, Rahman MM, Rahman M, Anwar AKM, 2003. Efficacy of ivermectin against gastrointestinal nematodes and ectoparasites in calves. Ind. Vet. J, 80:1173-1176.

15. Lamberg SL, Rothstein R, 1977. Laboratory Manual of Hematology and Urinalysis. Avi. Publishing Company, Inc, West Port Connecticut, U.S.S.R.

16. Mason CS, Offer JE, 2004. Fascioliasis associated with metabolic disease in a dairy cow and its effects on health productivity. Aust Vet J, 69 (14): 195-198.

17. Maqbool A, Hashmi HA, Shafique M, Akhtar T, Ahmad M, Mahmood F, 2000. Epidemiology and chemotherapy of fascioliasis in goats. India Journal of Animal Research, 34(1): 33-36.

18. Mamun MA, Bhuiyan MJU, Zinnah MA, Hassan MM, Atikuzzaman M, Uddin MB, 2011. Prevalence of Fasciola sp. infection in ruminants. Eurasian J Vet Sci, 27, 4, 241-244.

19. Mooney L, Good B, Hanrahan JP, Mulcahy G, De Waal T, 2009. The comparative efficacy of four anthelmintic against a natural acquired Fasciola hepatica infection in hill sheep flock in the west of Ireland. Vet Parasitol, 164, 201205.

20. Okoli IC, 2001. Analysis of abattoir records for Imo State, Nigeria, 1995-1999: Disease incidence in cattle, sheep and goats. Intl. J. Agril. Rural Dev, 2, 97-103.

21. Okewole EA, Ogundipe GA, Adejinmi JO, Olaniyan AO, 2000. Clinical evaluation of three chemo prophylactic regimes against ovine helminthosis in a fasciola endemic farm in Ibadan, Nigeria. Israel $\mathrm{J}$ Vet Med, 56, 1528.

22. Prasad KD, Parvin B, Bharti P, 2001. Assesment of oxyclosanide efficacy against chronic fascioliasis or paramphistomiasis in cattle and buffaloes. Journal of Research, 13(2): 245-248.

23. Queiroz GR, Filho LFCC, Zanluchi AT, Junior FABM, Okano W, 2013. Effect of dilatation of the cerebral ventricles after the administration of nitroxynil in swiss albino mice during organogenesis. Arch Vet Sci, 18, 23-28.

24. Russel DF, 1996. MSTAT Director. Crop and soil science department, Michigan state university, USA.

25. Ram H, Rasool TJ, Sharma AK, Meena HR, Singh SK, 2007. Comparative efficacy of different anthelmintic against fenbendazole resistant nematodes in Pashmina goats. Vet. Res. Commun, 31: 719-723.

26. Sahoo N, Mohanty TN, Patra BK, Mallick HN, Small S, 2002. Efficacy of oxyclosanide, closantel and triclabendazole against Fasciola infection in cattle a field trial in rainfed area of Orissa. Indian Veterinary Journal, 79(8):774775.

27. Snedecor GW, Cochran WG, 1967. Statistical Methods. Fifth Edn. The lowa State Univ. Press, Ames lowa, U. S. A.

28. Soulsby EJL, 1986. Helminth, Arthropods and Protozoa of Domesticated animals, $7^{\text {th }}$ edition. The ELBS and Bailiers, Tindal, Cassell, London, p-216,234,763-766.

29. Samad MA, 1996. Pashu Palon O Chikitsavidya. 1st pub. Lyric-Epic Prokashoni, Bangladesh Agricultural University Campus, Mymensingh, Bangladesh.

30. Tibbo M, 2000. The effect of triclabendazole (FasineX $®$ ) on acute fascioliasis in sheep in central highland of Fthipola. Bulletin of Animal Health and Production in Africa, 48(2):87-92.

31. Tahir M, 2002. Epidemiology of fascioliasis in Pakistan with special reference to southern Punjab. Pak Vet J, 12, 134.

32. Tariq KA, Chishti MZ, Ahmad F, 2010. Gastro-intestinal nematode infections in goats relative to season, host sex and age from the Kashmir valley. India J Helminthol, 84(1):937.

33. Velarde FI, Cristion NM, Montenegro YV, Bocanegra C, Campos AH, Calban PO, 2002. Comparative efficacy of an experimental fasciolicide, triclabendazole and closantel in cattle naturally infected with Fasciola hepatica. Veterinaria Mexico, 33(3):237-245.

34. Waller PJ, 2006. Sustainable nematode parasite control strategies for ruminant livestock by grazing management and biological control. Anim. Feed Sci. Technol., 126:277-289.

35. Yuliang J, Zang B, 1997. Epidemiological survey of Fascioliasis in Pakistan. Trop. J. Parasitol, 48, 302-303. 